\title{
RSP Revisitada Em prol de um Código de
Ética para o serviço público
}

Harvey Walker

Texto publicado na RSP, vol. I, no 2, de fevereiro de 1953

\begin{abstract}
Nesta edição, A RSP revisitada traz o artigo de Harvey Walker, publicado em 1953, dedicado ao tema da ética no serviço público. A preocupação do autor com a necessidade de um código de ética abrangente para o servidor público, que definisse padrões de conduta esperados dos representantes do Estado, revela-se bastante atual quando observamos que diversos tópicos abordados se colocam no debate contemporâneo.
\end{abstract}

Em quase todos os países e épocas tem havido funcionários que prostituem a função pública em benefício de um partido político, de amigos, parentes ou em benefício próprio. Alguns dos que assim procedem são chamados a responder perante os tribunais ou perante a opinião pública e então usualmente se justificam afirmando que outros adotaram a conduta que em seu caso é condenada.

As culturas diferem no grau de censura que impõem ao uso indevido das coisas públicas. Em alguns países, os defraudadores do erário, os traficantes de favores públicos, são punidos severamente. Países há em que essas faltas são castigadas com multas, prisão e perda do cargo; em outros, a pena é sòmente de demissão. Já, em outros a desonestidade nos serviços públicos tem dominado por tão longo tempo que é aceita pacientemente pelo público: a conduta sem ética e até imoral provoca um encolher resignado de ombros e o faltoso continua em seu pôsto. 
Não seria lógico esperar um tipo universal de reação pública ante a desonestidade. Cada cultura tem seus próprios padrões. São êles aprendidos no lar, na escola, na igreja e em todos os demais contatos sociais. O caráter é formado pelos preceitos e exemplos recebidos nos primeiros anos de vida. Um clima ético é o fator cultural formado das normas de educação e dos hábitos de pensamento da grande massa do povo. Não podemos esperar que os servidores públicos, que saem dessa massa, tenham, em geral, padrões éticos diferentes daqueles de seus amigos e vizinhos, tanto no serviço público como fora dele. Diz bem Kefauver: "enquanto o próprio código moral do cidadão não o impedir iludir-se a si mesmo (como acontece no caso de se corromperem os servidores públicos) o problema da corrupção e da moralidade na vida pública continuará a ser muito real e agudo".

Alguns procuram solução para o problema através da ação da igreja organizada. Evidentemente, será necessário mais que uma simples pregação para que se consiga um resultado substancial. Tôdas as principais regiões do mundo ensinam a boa conduta nas relações sociais. Mas o esfôrço heróico dos homens de boa vontade e dos líderes religiosos não impediu que ocorressem e ainda ocorram muitos casos de desonestidade no exercício das funções públicas.

Muitos estudiosos do govêrno e da administração pública crêem que uma das soluções seria fomentar e desenvolver um alto senso de responsabilidade profissional entre os próprios funcionários públicos. Talvez tenhamos - afirmam - dependido por tempo demasiado longo de leis repressivas e regulamentos oficiais para reger a conduta dos servidores públicos.
Seria interessante tentar uma experiência de auto-regulamentação dos mesmos. Propõem, por isso, que se organizem os funcionários em uma associação profissional, formada de grupos segundo o nível hierárquico dos servidores. Cada grupo teria a tarefa de estabelecer normas de conduta para seus respectivos membros e de informá-los das mesmas. Cada novo funcionário deveria conhecê-las e comprometer-se a cumpri-las. Os casos de infração do código de conduta funcional seriam analisados à luz dessas normas, por meio de uma comissão de disciplina. Tal comissão teria o direito de impor multas e outros tipos de penalidade, como a de suspensão e até demissão. Uma comissão assim constituída estaria sempre mais vigilante e seria mais realista na aplicação do código de ética que os tribunais que, raramente, estão a par dos problemas da administração.

Parece óbvio que a criação de um código de ética para os servidores públicos requereria muito tempo e deveria ser obra de muitos indivíduos. Outros grupos de profissionais já criaram seus códigos de ética. Os médicos e advogados do serviço público devem respeito a códigos próprios, elevados e severos, de ética profissional e que são respeitados por todos os que se dedicam ao exercício da profissão em caráter privado. Mas, para o administrador em geral, o escriturário, o mensageiro, o técnico, em função pública, não há outro código de referência que não seja o código criminal ou a própria consciência. Apresentamos na página seguinte o esboço de um código que poderá servir de exemplo do que seria o de ética para um servidor público. Talvez tivesse êle maior influência que um código criminal ou um estatuto dos funcionários para levar cada servidor público a adotar certos 
preceitos fundamentais para suas atividades. Um código de ética pelo menos reforçaria os outros. Em cada país, os servidores públicos responsáveis poderiam encarregar-se de criar um para seus próprios serviços. Muito concorreria isso para o estabelecimento de padrões profissionais e de uma atmosfera em que a carreira pública baseada no sistema de mérito, pudesse crescer e desenvolver-se.

\section{Esbôço de um código de ética para servidores públicos}

1) Reconheço que é alta honra a ser escolhido para servir o público. Hei de esforçar-me continuamente por provar que sou digno de tal confiança. Nunca praticarei, voluntàriamente, qualquer ato que me desqualifique ou me incapacite para o cumprimento de meus deveres.

2) Reconheço que aquêles com quem tenha contato hão-de considerar-me representante do governo e seu servidor. Conduzir-me-ei sempre com dignidade e cortesia, de forma a merecer confiança e apoio.

3) Desde que sou servidor de todo o povo, não serei parcial com qualquer indivíduo ou grupo no desempenho de minhas funções públicas.

4) Meu salário e outras vantagens são fixados pelos representantes do povo, visando compensar-me por todos os meus serviços como empregado público. Assim, não solicitarei e não aceitarei qualquer outro pagamento, dádiva ou favor, monetário ou não, de qualquer pessoa, para que me desincumba de qualquer função pública ou cumpra o meu dever. Isto se refere não sòmente ao trabalho feito por mim durante minhas horas usuais de expediente, em meu lugar de trabalho, como também a qualquer outro tempo ou lugar. Se considerar meus vencimentos inadequados, apelarei sòmente para o corpo legislativo, que fixa os salários dos servidores públicos, tendo em vista o aumento que me pareça necessário.

5) Nunca me aproveitarei de informações sôbre negócios públicos, que venham a ser de meu conhecimento durante o curso de minhas atividades funcionais, ou em conseqüência das mesmas, para minha vantagem pessoal ou a de qualquer outra pessoa, firma ou emprêsa.

6) Nunca praticarei, particularmente, qualquer ato de que me envergonharia se viesse a tornar-se notório. Tampouco negarei aos representantes acreditados pelos órgãos responsáveis informação pública, acesso a livros, documentos e arquivos, a menos que tenham sido declarados secretos pelo poder legislativo.

7) Serei escrupulosamente honesto na gestão de fundos públicos e na conservação dos bens do Estado, tratando-os com cuidado maior do que o dispensado aos meus próprios. Nunca usarei propriedades públicas que estejam sob minha guarda para fins pessoais nem permitirei que outros o façam. Nunca confundirei dinheiro público com o de minha propriedade. Honesta e francamente farei declaração sôbre o montante e a natureza de meus haveres pessoais, ao ingressar no Serviço Público, declaração que também farei ao deixar o mesmo serviço estando disposto a dar conta minuciosa de qualquer aumento que se tenha verificado nos mesmos haveres pessoais.

8) Cumprirei prontamente, da melhor maneira que fôr capaz, tôdas as minhas obrigações de cidadão.

9) Não aceitarei emprêgo que seja incompatível com o cumprimento de minhas obrigações públicas, tanto no que se refira a horas como natureza do 
trabalho ou sem o conhecimento e consentimento de meus superiores hierárquicos no Serviço Público.

10) Não buscarei ou aceitarei qualquer privilégio em virtude de minha posição no Serviço Público, a menos que o mesmo tenha sido conferido em conformidade com a lei geral. Em minhas representações perante o corpo legislativo pleiteando melhores condições de trabalho, falarei sòlenemente em nome de minha classe, nunca em meu nome próprio.

11) Reconheço ter a obrigação, perante meus empregadores, o povo, de esforçarme continuamente para aperfeiçoar-me, de modo que possa servi-los com mais eficiência. Esforçar-me-ei, durante tôda a minha carreira no Serviço Público, por aprender o mais possível a respeito de cada função que ocupar, preparando-me para maiores responsabilidades que me possam ser conferidas por promoção

12) Prometo apoiar meus superiores enquanto servirem êles ao público e obedecerem às leis que lhes cumprem administrar. Sempre que sinta ser impossível lhes ser leal por estar em desacôrdo com sua política, farei as representações próprias perante as autoridades competentes e se as diferenças acaso existentes não puderem ser afastadas pedirei minha demissão. Não buscarei notoriedade, mas não esconderei dos órgãos de publicidade as razões que me impeliram a tal procedimento.

A êsses doze cânones ou afirmações, muitos outros poderiam ser acrescentados; mas serão êles suficientes para ilustrar a natureza de um código de ética para os serviços públicos.

Cumpre que sublinhemos mais os deveres e responsabilidades dos servidores públicos do que seus direitos. Enfim, em uma democracia, os direitos de um servidor público não podem ser maiores que os conferidos a qualquer cidadão. Não obstante, seus deveres são muito maiores. Precisamos ter uma compreensão mais ampla da fôrça moral que é - ou deve ser - a do funcionalismo. Se puder autocontrolar-se, merecerá a confiança e a aprovação de todos; em caso contrário, nossa democracia se enfraquecerá constantemente. 